\title{
Using information logistics techniques to develop an integrated information pool for improving efficiency of post-clearance customs control
}

\author{
Oxana V. Bleikher \\ Department of History and Philosophy of Science and \\ Technology \\ National Research Tomsk Polytechnic University \\ Tomsk, Russia \\ e-mail: iforya@tpu.ru \\ Vera V. Ageeva \\ Department of History and Philosophy of Science and \\ Technology \\ National Research Tomsk Polytechnic University \\ Tomsk, Russia \\ e-mail: iforya@tpu.ru
}

\author{
Oxana E. Brazovskaya \\ Department of History and Philosophy of Science and \\ Technology \\ National Research Tomsk Polytechnic University \\ Tomsk, Russia \\ e-mail: iforya@tpu.ru \\ Natalya B. Butorina \\ Department of Applied Mathematics and Programming \\ National Research Tomsk State University \\ Tomsk, Russia \\ e-mail: nnatta07@mail.ru
}

\author{
Alexander V. Kuleshov \\ Department of customs operations and customs control \\ St. Petersburg branch of the Russian Customs Academy \\ St. Petersburg, Russia \\ e-mail: avk@spbrca.ru
}

\begin{abstract}
A key issue in Russian post-clearance customs control is the automation of customs procedures and day-to-day customs management at national and regional levels, as well as the building of a single information space. In order to expedite Russian post-clearance customs control, it is necessary to develop an integrated information system, which includes three levels: post-clearance currency control of goods, checking of customs documents, tax control of declarations. The article's purpose is to develop the architecture of integrated information pool for improving efficiency of post-clearance customs control in the Russian Federation. Research results demonstrate that suggested methodology for data integration of customs, currency and tax control is relevant to the information sharing and sensitization of customs authorities for an appropriate choice and timely application of methods and forms of post-clearance customs control. It will contribute to collecting, integrating and providing information in automated mode for all aspects of customs activities.
\end{abstract}

Keywords-database; single information space; international trade; information logistics; information pool

\section{INTRODUCTION}

Modern information technologies are used in foreign trade at all stages of the economic and customs operations. Currently, many large organizations use databases in their management. Of course, the database reduces the time to find useful information. The term "database" refers to a specially organized storage of information resources (collection of files) as an integrated system, providing convenient communication between them and the fast access to data [1]. One of the basic principles of the database creation is that the information system should be the basis for building concretized model of information services for professionals [2].

The need for simplification of customs procedures, the dilemma between the objectives of the development of foreign economic relations and ensure compliance with the measures of state regulation imposes certain restrictions on the use of traditional ways such support, encourage the search for new forms of post-clearance customs control.

According to the development strategy of the Customs Service of the Russian Federation until 2020, one of the main challenges is process automation, providing the possibility of control in the process of customs declaration when placing goods under the customs procedure and after their release, and realizing the opportunity to obtain the necessary information from the resources of the Central Database of Unified automated information system of customs authorities and the resources under the jurisdiction of the federal bodies of executive power [3].

The relevance of this study consists in the need to solve problems in Russian customs authorities in the creation of a 
single interagency automated system of collection, storage and processing of information in the implementation of all types of state control, including pairing database of tax service and customs authorities of the Russian Federation to strengthen customs control after release of goods in circulation in the customs territory of the Russian Federation (monitoring-based audit methods).

The criteria (indicators) of the effectiveness of information technology policy, reflecting the degree of improvement in performance of the customs authorities of its core functions in relation to the costs of carrying out organizational and technical measures are:

- Integration degree of information resources of customs authorities with the information systems of other ministries and departments of the Russian Federation as well as with information systems of the customs services of the Eurasian Economic Union member states and the Commonwealth of Independent States (CIS) member states;

- Protection of customs information from unauthorized access and leakage through technical channels;

- Qualitative characteristics of information flows, their volumes, timing of processing and transmission (presentation) of information by the customs authorities, the operational monitoring of customs activities;

- Supportability of customs authorities with modern information technical tools and security systems.

The relevance of this study is dictated not only the management decisions of Russian Federal Customs Service and other governmental structures, but also the objective laws of social and technical development. For instance, computerization of customs procedures requires highly skilled specialists-technicians who would be able to provide all the information operations. The research focus is information technology related to the processing and storage of information on foreign trade and its subjects including databases that are used in the process of customs control after the release of the goods, their nature and purpose.

The purpose of the article is to develop the architecture of integrated information pool to increase the efficiency of postclearance customs control in the Russian Federation.

\section{MATERIALS AND METHODS}

To accomplish the goal, we should solve following tasks:

- Consider the nature of information technology;

- Review the specifics of information technologies used in customs post-clearance control;

- Explore the significance of tax, banking and customs data, which make up the database used in the customs control after release of goods;

- Design a common architecture of information integration to create an integrated computerized database to improve the efficiency of customs postclearance control.

The main problem in the integration of the database used in the implementation of customs control after release of goods in a single information pool is the complexity of using methods and insufficient information logistics software.

The research method is the comparative analysis of the information received from various sources and its synthesis. We analyzed the modern information technologies, and in particular the database used in the implementation of customs control after the release of the goods. The comparative method helps to establish the general and specific features of the subject under study and its activities. We also used the techniques and methods of general scientific knowledge of induction and deduction, synthesis, analogy.

\section{LITERATURE REVIEW}

Simplification and harmonization of customs procedures, and improvement of the efficiency of customs control have a special place in the modern research field at the intersection of law, economic sciences and information technologies $[4 ; 5 ; 6]$.

Special weight in the study takes a monograph of E.V. Moiseenko and E.G. Lavrushina "Information technology in the economy" which describes the main sources of information on foreign trade and the purposes of their use [7]. The article of N.M. Kozhukhov "Analysis of the problems of information integration in customs", which analyzed aspects of the incomplete formation of a unified database for customs control in general, is of particular interest [8].

An analysis of regulatory legal acts of the Eurasian Customs Union and the Eurasian Economic Union was made, which govern the use of information technology in the field of customs.

It should be noted that in this area of scientific knowledge there are enough issues that require judgment and the development of common approaches aimed at identifying ways of forming a unified database to improve the efficiency of customs control.

\section{RESULTS AND DISCUSSION}

The effectiveness of the use of information technology is determined by the successful organization of the next stages of collecting socio-legal information: the development of the program; selection and training of artists; creation of organizational, legal, logistics conditions and environment for their creative work.

Also, to ensure the effective protection of information is a primary legal aspect, namely the need for a clear separation of information objects in order to legally define the legal status of each of them [9]. The legal regime of information as an object of legal regulation in the first place, must be considered from the standpoint of its availability.

An important area for further development of the system of customs control after release of goods, improving the mechanisms for customs clearance and control, improve the 
transparency of customs procedures is the automation of customs technologies and operational management of customs activities, providing formation and bring in automatic mode to the customs authorities in all areas of their activities.

Studies have shown that today customs automation technology requires a new organization of the automated information system, namely:

- Consolidated and centralized storage of customs documents in the electronic image;

- Remote users access the system to its information resources on protected WEB-based technology;

- Object-oriented architecture of the automated system;

- Centralized administration of information network and database from the Main Research Computing Center in Russian Customs Services;

- Implementation in an automated risk management procedures;

- Automated risk management procedures and monitoring after the release of goods in accordance with the declared (customs post audit) [10].

Thus, to accelerate the post-entry control, it is possible to develop a single information system, which includes three levels: currency control after release of goods, customs control, customs documents, tax audit declarations.

Software for automation of customs post-clearance control should:

- exchange information with the automated information system "Tax", the Unified automated information system and a bank automated systems (information resources of local, regional and federal levels);

- allow to formalize the formation of the output information, including the results of foreign exchange controls, analysis of goods declarations, customs receipt, the declarations of the customs value and control field tax audit;

- to carry the load of data on foreign trade transactions, accounting and tax records of the taxpayer and customs declarations data to the database system.

The general structure of information integration of the Federal Customs Service and other state bodies of executive power of the Russian Federation is shown in Figure 1.

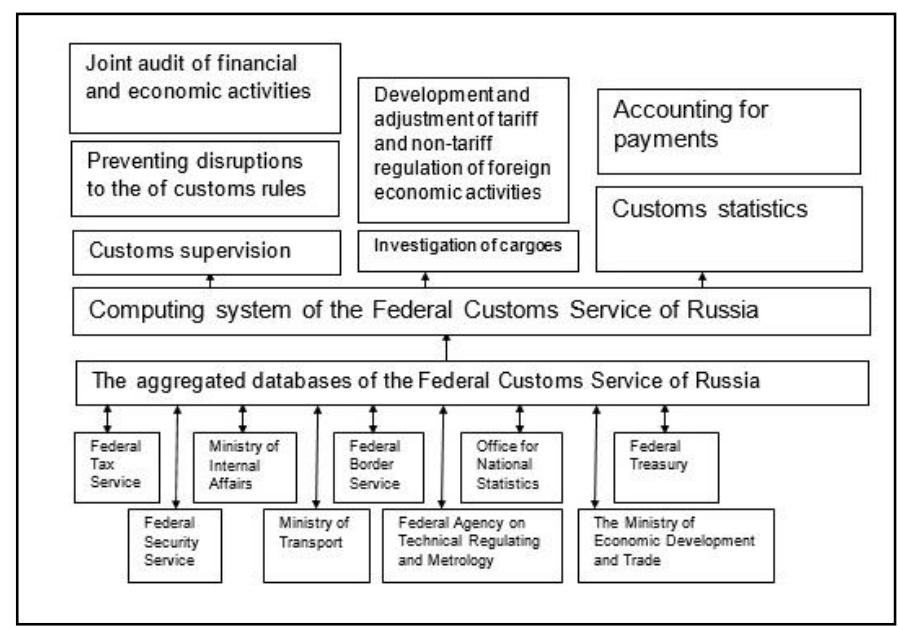

Fig. 1. Information integration of the Federal Customs Service and other state bodies of executive power.

The overall structure of information integration of Russian Customs Service and other state bodies of executive power of the Russian Federation includes Aggregate Databases of Russian Customs Service, computer system of Russian Customs Service, maintaining customs statistics, records of receipt of payments, joint inspections of financial and economic activity, prevention of violations of customs regulations, tracing cargo, development and adjustment of tariff and non-tariff measures of regulation of foreign economic activity, and other elements (See Table 1).

TABLE I. GENERAL INFORMATION ABOUT THE PARTICIPANTS OF FOREIGN TRADE INCLUDED INTO DATABASES OF CUSTOMS, CURRENCY AND TAX CONTROL

\begin{tabular}{|c|c|c|c|}
\hline \multirow[b]{2}{*}{ Type of data } & \multicolumn{3}{|c|}{ Type of Database } \\
\hline & $\begin{array}{c}\text { Database } \\
\text { of } \\
\text { exchange } \\
\text { control }\end{array}$ & $\begin{array}{c}\text { Database } \\
\text { of tax } \\
\text { control }\end{array}$ & $\begin{array}{c}\text { Database } \\
\text { of } \\
\text { customs } \\
\text { control }\end{array}$ \\
\hline \multicolumn{4}{|l|}{ I. Participant details: } \\
\hline Certificate of state registration & + & + & + \\
\hline $\begin{array}{l}\text { Date of registration in the State } \\
\text { Statistical Committee }\end{array}$ & + & + & + \\
\hline \multicolumn{4}{|l|}{ II. Bank details: } \\
\hline $\begin{array}{l}\text { Name and address of the bank } \\
\text { (account holder) }\end{array}$ & + & & + \\
\hline $\begin{array}{l}\text { Current account of the resident } \\
\text { bank }\end{array}$ & + & + & + \\
\hline \multicolumn{4}{|l|}{ III. Information on the taxpayer: } \\
\hline Date of registration & & + & \\
\hline Certificate of Registration & & + & + \\
\hline $\begin{array}{l}\text { Name and address of the tax } \\
\text { authority }\end{array}$ & & + & + \\
\hline \multicolumn{4}{|c|}{ IV. Information on the customs authority: } \\
\hline $\begin{array}{l}\text { Customs Code (in which a } \\
\text { trader operates) }\end{array}$ & + & & + \\
\hline $\begin{array}{l}\text { Address customs department } \\
\text { (customs post) }\end{array}$ & + & & + \\
\hline Account number card party & + & + & + \\
\hline \multicolumn{4}{|l|}{ V. Information about the contract: } \\
\hline Contract Number & + & & + \\
\hline Date of execution of the contract & + & & + \\
\hline $\begin{array}{lccc}\text { Term of } & \text { payment } & \text { for } \\
\text { export/import } & & \\
\end{array}$ & + & & + \\
\hline \multicolumn{4}{|l|}{ VI. passport transaction: } \\
\hline Number of transaction passport & + & + & + \\
\hline \multicolumn{4}{|l|}{ VII. Data on payments: } \\
\hline Information about payment & + & + & + \\
\hline
\end{tabular}

To identify the organization or person engaged in foreign economic activities related to the movement of goods through the customs border of the Customs Union (hereinafter the customs border of the Eurasian Economic Union) is necessary 
to create a common database to provide timely and objective information to further the integration of information resources available to the customs authorities.

There is similar information in the databases of all three types of control (currency, tax, customs), presented in tabular form below, you want to make into a common database [11]. They include: details of participant of foreign economic activities, bank details, information about the taxpayer, information about the customs authority, information about the contract, information about the transaction and the passport details of payments.

Information technology integration of customs, currency and tax control actually used to inform and orientation of customs offices in the timely selection and application of appropriate forms and methods of customs control after the release of the goods.

The technology will allow to:

- reduce the time of customs clearance and increase the efficiency of customs control by referring to the stage of post-entry control issues related to those aspects of foreign trade transactions, which cannot be full and complete check in process of customs clearance;

- provide additional revenues by increasing customs and tax payments, as well as by identifying schemes of evasion from payment of customs payments;

- encourage the discipline of participants of foreign trade activities, to ensure the prevention of crime, improve the quality of law enforcement, customs authorities;

- reduce transport and other costs of participants of foreign trade, ensure the acceleration and increase of trade turnover between the two countries.

\section{CONCLUSION}

Thus, the formation of a single database - a central information pool is one of the most important tasks to improve as the customs control after release of goods, and customs control in general. This will speed up the process of customs checks and to improve its quality, which should have a positive impact on the economic situation of the country.
In the transition to a unified information system of postentry control state bodies, controlling foreign economic activity, will be able to with the help of computer programs: control and accuracy of formation of indicators of customs, tax returns and passports of foreign trade transactions on the basis of the data obtained in the course of a customs audit; calculate the amount of taxes based on the results of other similar taxpayers in case of impossibility of reliable determination of the tax; implement "categorization" of agents of foreign economic activity to accelerate the modernization of the control activities and Risk Management System.

\section{REFERENCES}

[1] Audit database, URL: http://dvfo.gnivc.ru/about/base_audit/

[2] S.D. Kuznetsov, "Fundamentals of modern databases," Informationanalytical materials of the Center of Information Technologies, URL: http://citforum.ru/database/osbd/contents.shtml

[3] "Development Strategy of the Customs Service of the Russian Federation until 2020," Order of the Government of the Russian Federation on December 28, 2012 №2575 p.

[4] O. Bleikher, and N. Trubnikova, "Use of information technology for the study of conditions for the development of small and medium-sized businesses in the region," Proceedings of 2014 International Conference on Mechanical Engineering, Automation and Control Systems, MEACS 2014. DOI: 10.1109/MEACS.2014.6986906

[5] A. Awad, R. Gore, Z. Hou, J. Thomson, and M. Weidlich, "An iterative approach to synthesize business process templates from compliance rules," Information Systems, 2012, No 37(8), pp. 714-736. DOI: 10.1016/j.is.2012.05.001

[6] L. Urciuoli, J. Hintsa, and J. Ahokas, "Drivers and barriers affecting usage of e-Customs - A global survey with customs administrations using multivariate analysis techniques," Government Information Quarterly, 2013, vol. 30, issue 4, pp. 473-485.

[7] E.V. Moiseenko, and E.G. Lavrushina, Information technology in the economy, St. Petersburg, 2013.

[8] N.M. Kozhuhov, Analysis of the problems of information integration in customs, Russian Customs Academy, Moscow region, Lyubertsy, URL: http://www.tsouz.ru/db/it/Documents/9_1.pdf

[9] "On approval of the organization of processes of software life cycle of information systems and information technologies customs authorities," The Order of the Federal Customs Service of Russia from 03.02.2010 №183.

[10] A single archive of sociological and economic data, URL: http://sophist.hse.ru/4dbank.shtml

[11] The theory of information processing, URL: http://book.kbsu.ru/theory/chapter6/1_6_17.html 